\title{
Makna Semiotik Kesenian Buncis Angklung bagi Masyarakat Desa Tanggeran di Banyumas
}

\author{
Rifiana Abdul Razzak \\ Chalidana Islamic School, Sidoarjo, Jawa Timur, Indonesia \\ ${ }^{(*)} \bowtie$ (e-mail) ivan.skateady@gmail.com
}

\begin{abstract}
Abstrak
Seni dikatakan sebagai sebuah ekspresi manusia yang bersifat estetis dalam kehidupan masyarakat memiliki makna semiotik yang beragam. Buncis Angklung merupakan kesenian tradisional yang memiliki keterkaitan sejarah dengan Desa Tanggeran dan memiliki makna semiotik bagi masyarakatnya. Tujuan dari penelitian ini adalah untuk mengetahui, menjelaskan, dan mendeskripsikan perwujudan makna semiotik kesenian Buncis Angklung yang berasal dari Desa Tanggeran Kecamatan Somagede Kabupaten Banyumas. Penelitian dilakukan dengan metode kualitatif dan pendekatan interdisipliner. Pengumpulan data menggunakan metode observasi, wawancara, dan studi dokumen. Analisis data seni dilakukan pada aspek intra dan ekstraestetik. Hasil penelitian menunjukan bahwa: (1) Kesenian Buncis Angklung memiliki rangkaian tahapan pertunjukan, yaitu tahap sebelum pertunjukan, saat pertunjukan, dan setelah pertunjukan. Pertunjukannya berupa tarian yang penarinya memainkan angklung sebagai iringan tarinya. (2) Dalam teks pertunjukan Buncis Angklung ditemukan adanya makna religius dan makna relasi.
\end{abstract}

Kata kunci: buncis angklung, makna semiotik, kebudayaan banyumas

\begin{abstract}
An art is stated as a form of a human expression which possesses aesthetic value. It has various semiotic meanings in society. Buncis Angklung is a traditional art from Tanggeran village which has direct connections to the history of Tanggeran and has various semiotics for Tanggeran people. This research aimed to find out, explain and describe the exhibition, the semiotic meanings behind Buncis Angklung Performing Art from Tanggeran Village, Somagede, Banyumas. This study applied qualitative method with an interdisciplinary approach. In collecting the data, observation, interview and past document studies were conducted. The data analysis covered the intra-aesthetic and extra-aesthetic aspects of the artworks. The results of the study revealed that: (1) Buncis Angklung Performing Art was a performance art in which the dancers play angklung along with the dancing movement. There are three stages in performing this art: before the performance, the performance and after the performance. (2) Buncis Angklung revealed that the religious and relation meanings exist in Buncis Angklung peformance script.
\end{abstract}

Keywords: buncis angklung, semiotic meanings, banyumasan culture

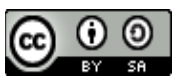

This work is licensed under a Creative Commons Attribution-ShareAlike 4.0 International License. Copyright (C 2021 Rifiana Abdul Razzak

Proses Artikel

Diterima 02-06-2021; Revisi 23-06-2021; Terbit Online 24-06-2021 


\section{Pendahuluan}

Buncis Angklung merupakan kesenian yang berwujud pertunjukan tari sekaligus musik di dalamnya. Beberapa kajian terdahulu menyebutkan bahwa Buncis Angklung merupakan kesenian yang berasal dari Tanggeran yang memiliki beragam nilai-nilai di dalamnya (Indrayati, 2015; Merdiana, 2013; Sabar \& Wiyoso, 2018; Saputra, 2015). Hal tersebut diperkuat oleh keterangan Giwan dalam sebuah wawancara, yaitu sejarah Buncis Angklung yang ternyata memiliki keterkaitan dengan babad Desa Tanggeran, serta bukti-bukti otentik yang menunjukan keterkaitan diantara kedua hal tersebut.

Secara etimologi, Buncis merupakan singkatan dari kata 'bun' dan 'cis'. Kata 'bun' merupakan kepanjangan dari kata buntuning lelakon, habisnya ide dan upaya dalam memecahkan sebuah masalah atau dapat diartikan pula sebagai jalan buntu dalam sebuah pemikiran. Kata 'cis' merupakan bahasa Banyumasan yang memiliki arti sebuah senjata kecil yang terdapat di ujung tombak, atau ujung bambu yang berbentuk runcing, atau keris yang berukuran kecil dan memiliki makna konotasi yaitu sebuah ucapan seseorang. Dua suku kata tersebut berasal dari cerita atau babad Desa Tengger atau yang sekarang dikenal dengan nama Desa Tanggeran.

Terkait arti dari tiap suku katanya dan menurut sumber dari cerita babad Desa Tanggeran, Buncis memiliki arti kebuntuan pemikiran atau habisnya ide seorang Raden Patah Haji (putra angkat Ki Ageng Ampeldenta) untuk melarikan diri dari kejaran Patih Sundara dan Ki Ageng Kriyayuda yang ingin membunuhnya. Oleh sebab buntunya pemikiran Raden Patah Haji, akhirnya beliau mengambil sikap untuk berperang melawan Patih Sundara dan Ki Ageng Kriyayuda beserta prajuritnya. Saat itulah senjata yang dimiliki Raden Patah Haji, yaitu sebuah 'cis' atau ujung tombak yang berbentuk runcing, pemberian dari Sunan Ampel digunakan untuk menyerang dan menghujam tubuh Ki Ageng Kriyayuda. Pencatatan tentang babad atau sejarah kesenian Buncis dilakukan oleh kayim atau tokoh agama Islam di desa Tanggeran yang bernama Sumardi pada tahun 1951, kemudian ditulis ulang (tahun 2011) tanpa perubahan pada isi babad oleh pembina rombongan kesenian Buncis Angklung Ngudi Utomo yaitu Giwan.

Hadirnya pertunjukan di tengah masyarakat memiliki beberapa fungsi yang turut serta melekat dalams etiap penampilannya, baik sebagai ekspresi, hiburan, ritual maupun media pendidikan (Permanasari, Alis Triena; Setian, 2020; Putra, 2017; Sinaga, 2016; Winangsit \& Sinaga, 2020). Ketika Buncis Angklung ditampilkan pada saat ritual Baritan atau Mbarit, bertujuan untuk mengundang hujan dan mengusir malapetaka. Seiring dengan perkembangan teknologi dan informasi, upacara tersebut mengalami perubahan karena masyarakat mulai meninggalkan pola pikir yang dianggap kuno dan tidak logis (Sutopo et al., 2019).

Perwujudan kesenian Buncis Angklung dikaji menggunakan performance studies dengan uraian proses pertunjukan dari awal sampai akhir, meliputi before performance (sebelum pertunjukan), performance (saat pertunjukan), dan after performance (setelah pertunjukan) (Cahyono, 2014, p. 51; Schechner, 2013; Schechner \& Lucie, 2020). Tadeuz Kowzan dalam (Cahyono, 2014, p. 49) mengatakan bahwa dalam pertunjukan terdapat tiga belas sistem tanda, yaitu: (1) tanda kata, (2) nada, (3) mimik, (4) gerakan-gerakan, (5) gerak isyarat, (6) tata rias, (7) gaya rambut, (8) kostum, (9) properti, (10) setting, (11) tata cahaya, (12) musik, dan (13) pengaruh bunyi. Sistem tanda dari Kowzan akan diterapkan dalam kajian 
tentang kesenian Buncis Angklung, namun hanya dipilih beberapa sistem tanda yang dianggap relevan dengan aspek-aspek dalam sebuah pertunjukan seperti: (1) tanda nada atau musik, (2) pengaruh bunyi, (3) setting, (4) kostum, (5) properti, (6) tata rias, dan (7) gerakangerakan.

Berdasarkan uraian latar belakang di atas, penelitian ini akan mengkaji makna semiotik Buncis Angklung bagi Masyarakat Tenggeran. Tujuan dari penelitian ini antara lain untuk menjelaskan, mendeskripsikan, dan menganalisis tentang perwujudan makna kesenian Buncis Angklung bagi masyarakat Tanggeran di Kecamatan Somagede Kabupaten Banyumas.

\section{Metode}

Penelitian ini termasuk dalam penelitian kualitatif. Penelitian kualitatif digunakan untuk mengeksplorasi dan memahami makna yang oleh sejumlah individu atau sekelompok orang dianggap berasal dari masalah sosial (Creswell, 2016, p. 28). Penelitian ini menggunakan pendekatan semiotika, yang pada umumnya didesain untuk memahami atau mengukur suatu masalah kajian yang berada di luar tradisi kajian suatu disiplin ilmiah (Rohendi Rohidi, 2011, p. 65).

Penelitian ini dilakukan di Tenggeran - Jawa Tengah, Beberapa konsep perfomance studies digunakan untuk mengkaji beberapa data dalam penelitian ini, konsep tersebut terbagi menjadi tiga tahapan, yaitu tahap sebelum pertunjukan (before performance), tahap pertunjukan (performance), dan tahap setelah pertunjukan (after performance). Teknik pengumpulan data menggunakan observasi, wawancara, dan studi dokumen. Hasilnya berupa catatan lapangan, transkrip wawancara, rekaman wawancara, foto dan video serta berkas-berkas terkait. Analisis data seni dilakukan pada aspek intra dan ekstraestetik secara induktif dari mulai tema khusus ke umum, serta menafsirkan data.

\section{Hasil}

\section{Buncis Angklung Tanggeran dalam Pertunjukan}

Berikut uraian proses pertunjukan kesenian Buncis Angklung Tanggeran dari awal sampai akhir yang meliputi tahap sebelum pertunjukan (before performance), tahap pertunjukan (performance), dan tahap setelah pertunjukan (after performance).

Tahap Sebelum Pertunjukan (Before Performance)

Performance atau pertunjukan melibatkan empat unsur yaitu pelaku seni, interaksi penonton dengan pelaku seni, ruang, dan waktu (Septiana et al., 2016, p. 99). Tahapan dalam kajian pertunjukan menurut (Schechner, 2013; Schechner \& Lucie, 2020) dibagi menjadi tiga bagian dari awal hingga akhir, yaitu tahap persiapan pertunjukan (before performance), pertunjukan (performance), dan setelah pertunjukan (after performance). Before performance merupakan aktivitas yang dilakukan oleh para pemain Buncis Angklung dan masyarakat Grumbul Lampeng RT 08 / RW 01 Desa Tanggeran untuk menyiapkan segala sesuatu yang terkait dengan pertunjukan kesenian Buncis Angklung.

Karakteristik dari pertunjukan ritual adalah tempat yang terpilih, diperlukan seperangkat sesaji, tujuan lebih dipentingkan dari pada penampilan secara estetis, dan diperlukan busana yang khas (Soedarsono, 1999, p. 126). Waktu pementasan Buncis Angklung ditentukan oleh ketua atau pemimpin rombongan kesenian dan sesepuh desa, sesuai dengan penanggalan dalam kalender Jawa seperti Malam Jum'at Kliwon, Selasa Kliwon, Sabtu Pahing, 
dan sebagainya. Berkaitan dengan tempat pelaksanaan, pada dasarnya kesenian Buncis Angklung membutuhkan area yang luas seperti lapangan desa, pekarangan, dan halaman rumah yang luas. Kesenian Buncis Angklung dapat dipentaskan di mana saja dengan ukuran area stage minimal panjang 10 meter dan lebar 8 meter yang digunakan para pemain angklung untuk bergerak dan melakukan pola-pola lantai.

Sajen atau sesaji memiliki arti sebuah hidangan atau sajian makanan, minuman, dan bunga-bungaan yang ditujukan kepada makhluk halus (spiritual) atau roh leluhur sesuai dengan kepercayaan masyarakat (Sugono, 2013, p. 1244). Bagi orang Jawa upacara tradisi, ritual selamatan atau gelar sajen adalah peristiwa yang sudah diakrabi sejak lahir (Giri, 2010, p. 14). Pertunjukan Buncis Angklung selalu menggunakan sesaji sebagai kelengkapan dalam sebuah persiapan pertunjukan dengan tujuan agar selama pertunjukan diberikan kelancaran dan tidak ada gangguan apapun, sesuai dengan kepercayaan masyarakat Jawa terdahulu. Sesaji yang digunakan dalam pertunjukan Buncis Angklung antara lain adalah tampah atau nampan yang terbuat dari anyaman bambu, kembang telon (bunga tiga macam warna), dua telur ayam kampung, nasi tumpeng, pisang raja dan pisang kepok, cengkir (buah kelapa hijau) dan kelapa gading muda, daun teh kering, kopi bubuk, rokok kretek, ketupat satu janur (kupat slamet) dan ketupat dua janur, pohon padi kering, daun jati, daun suruh, kacang tanah, air putih, air dari bunga tiga macam warna, air kopi manis, air kopi pahit, air teh mains, air teh tawar, dan minyak duyung.

Musik tradisional mempunyai akar yang mendalam di dalam sebuah budaya. Calung Banyumasan memiliki keterkaitan atau kesinambungan benang merah dengan kesenian Buncis Angklung (Kuwat, 1999). Namun demikian, dalam kesenian Buncis Angklung, alat musik yang digunakan bukanlah calung, melainkan angklung, seperti yang tertera pada gambar 1. Angklung dalam kesenian Buncis Angklung merupakan alat musik bambu generasi ke dua setelah Bongkel di dalam sejarah perkembangan musik tradisional Banyumas (Kuwat \& Hastanto, 1999:37).

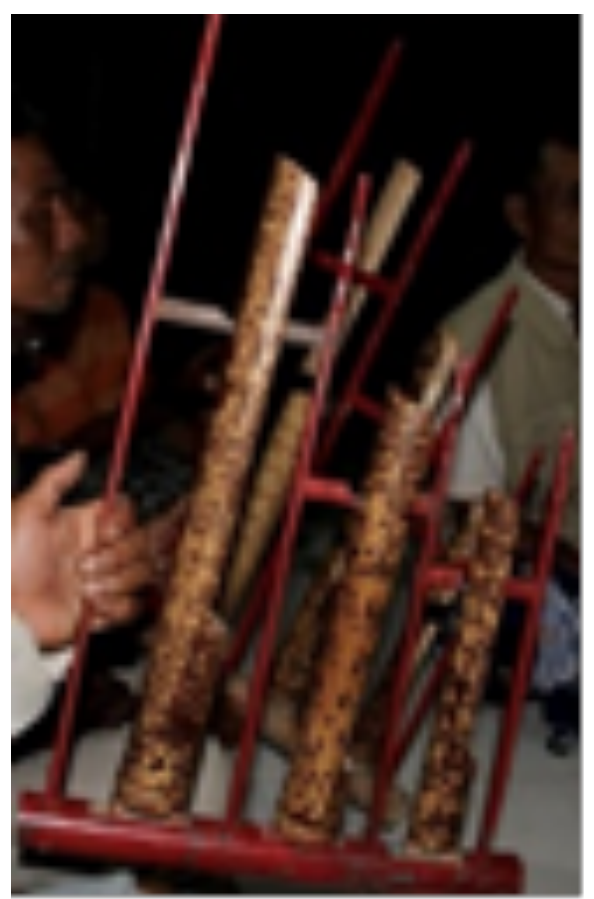

Gambar 1. Alat Musik Angklung pada Kesenian Buncis Angklung (Dokumentasi: Rifiana Abdul Razzak, 2016) 
Gambar 1. menunjukan sebuah angklung memiliki tiga bilah, tiap-tiap bilah berbeda frekuensinya (interval kwint dan oktaf). Laras atau tangga nada yang digunakan dalam satu set angklung Buncis adalah laras slendro, yaitu 2 (ro), 3 (lu), 5 (ma), 6 (nem), 1 (ji tinggi), 2 (ro tinggi). Cara memainkannya adalah digoyang-goyangkan supaya bilah-bilah bertabrakan hingga muncul bunyi dari bilah tersebut, karena angklung tergolong dalam alat musik keluarga idiophone, yaitu alat musik yang memiliki sumber bunyi tubuh alat atau bahan baku alat itu sendiri (Banoe, 2012, p. 13).

Alat musik selanjutnya dalam kesenian Buncis Angklung adalah sebuah kempul (idiophone) dan satu set kendang (membranophone). Di bawah ini merupakan gambar 2(a) yaitu kempul, dan gambar 2(b) yaitu kendang.

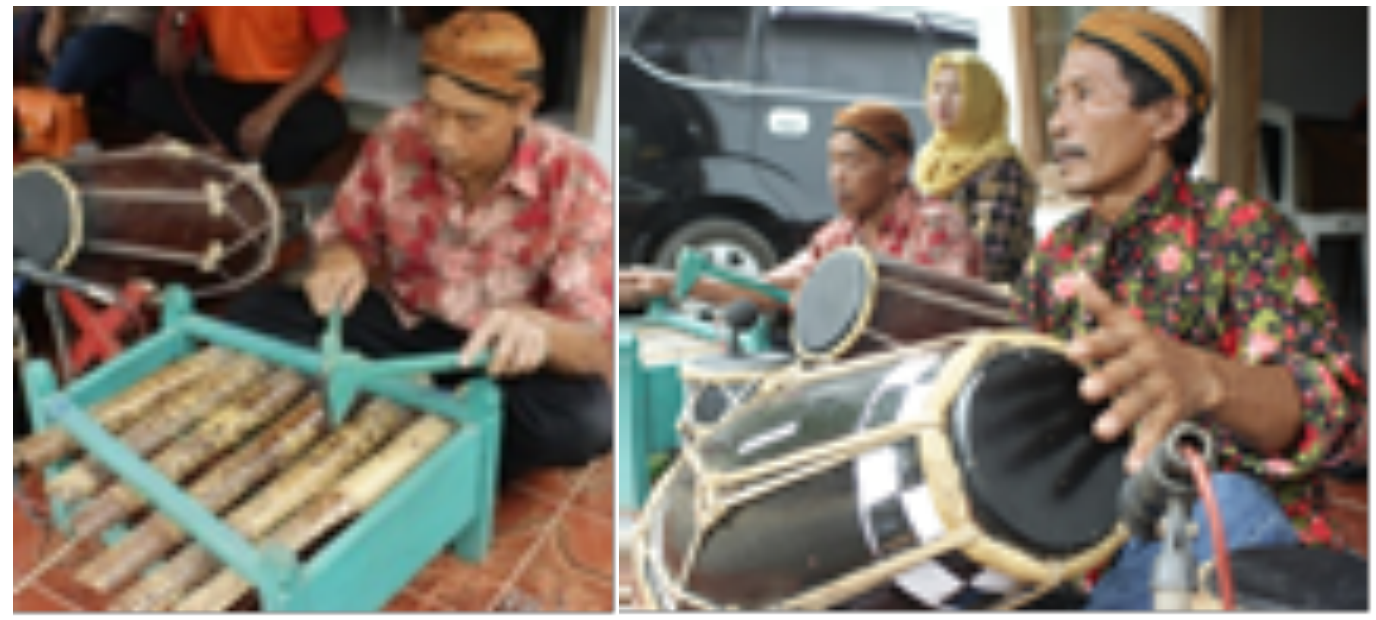

Gambar 2(a) Alat Musik Kempul (kiri), dan 2(b) Kendang (kanan) (Dokumentasi: Rifiana Abdul Razzak, 2016)

Selanjutnya terdapat Gong bumbung, yaitu alat musik tradisional Banyumasan yang menghasilkan nada rendah seperti halnya gong pada komposisi karawitan. Terdiri dari dua buah bambu, satu bambu berdiameter kecil yang dimasukan ke dalam bambu yang berdiameter lebih besar, dengan panjang kurang lebih 60-70 cm. Cara memainkannya bukan dipukul atau digoyang-goyangkan seperti angklung, melainkan ditiup (bambu yang berdiameter kecil) dengan getaran bibir sebagai sumber bunyi. Lihat gambar 3 di bawah ini.

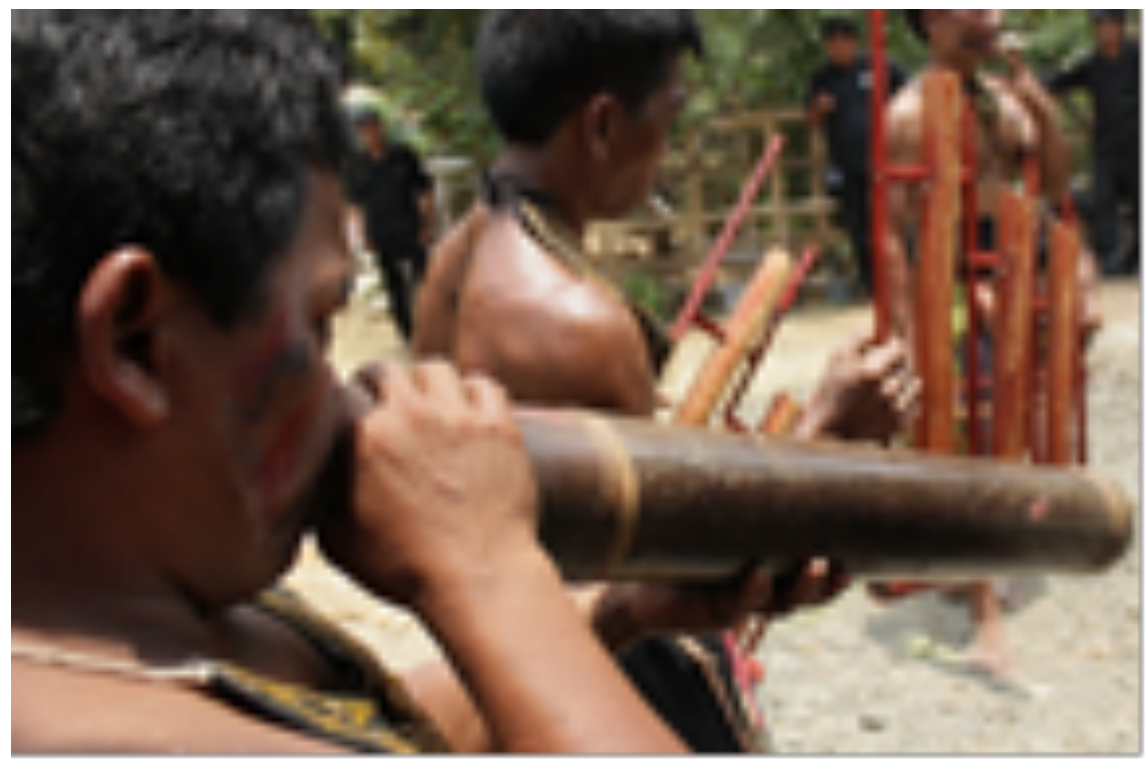

Gambar 3. Alat Musik Gong Bumbung (Dokumentasi: Rifiana Abdul Razzak, 2016) 
Kesenian Buncis Angklung dimainkan oleh delapan orang pemain angklung dengan nada yang berbeda-beda, satu orang pemain kempul, satu orang pemain kendang, satu orang pemain gong bumbung, dan seorang sinden.

Alat-alat musik dipersiapkan sebelum pementasan oleh para seniman Buncis Angklung. Jika pertunjukan Buncis Angklung dilaksanakan di sekitar Desa Tanggeran, maka alat-alatnya dipanggul atau dalam bahasa Indonesia berarti diangkat menggunakan tangan kosong dan diletakan dibahu atas (samping telinga) sampai ke tempat pertunjukan. Lain halnya jika tempat pertunjukan berada di luar daerah Tanggeran atau di luar jangkauan dengan berjalan kaki. Alat-alat musik dibawa menggunakan mobil milik Lurah Desa Tanggeran atau menggunakan mobil milik salah satu warga saat mobil milik Lurah Desa Tanggeran berhalangan. Tidak ada ritual khusus yang dilakukan untuk alat-alat musik, namun seniman Buncis Angklung menganggap bahwa alat musik yang digunakan dalam pertunjukan (terutama angklung) adalah instrumen yang istimewa karena proses pembuatannya yang tidak mudah.

Sebelum pertunjukan Buncis Angklung dilaksanakan, para pemain angklung melakukan rias terlebih dahulu. Rias wajah atau make up, rias tubuh atau body painting, serta busana atau kostum yang dikenakan oleh seorang seniman dalam pementasan merupakan salah satu hal yang menunjang sebuah kesuksesan pertunjukan. Tata rias dan tata busana yang digunakan dalam kesenian Buncis Angklung memiliki perbedaan dengan kesenian-kesenian Banyumasan yang lain, bahkan dengan kesenian-kesenian tradisional di Pulau Jawa. Sebab tata rias yang digunakan memunculkan karakter atau ciri khas dari suku Dayak dari Kalimantan. Lihat gambar 4 di bawah ini.

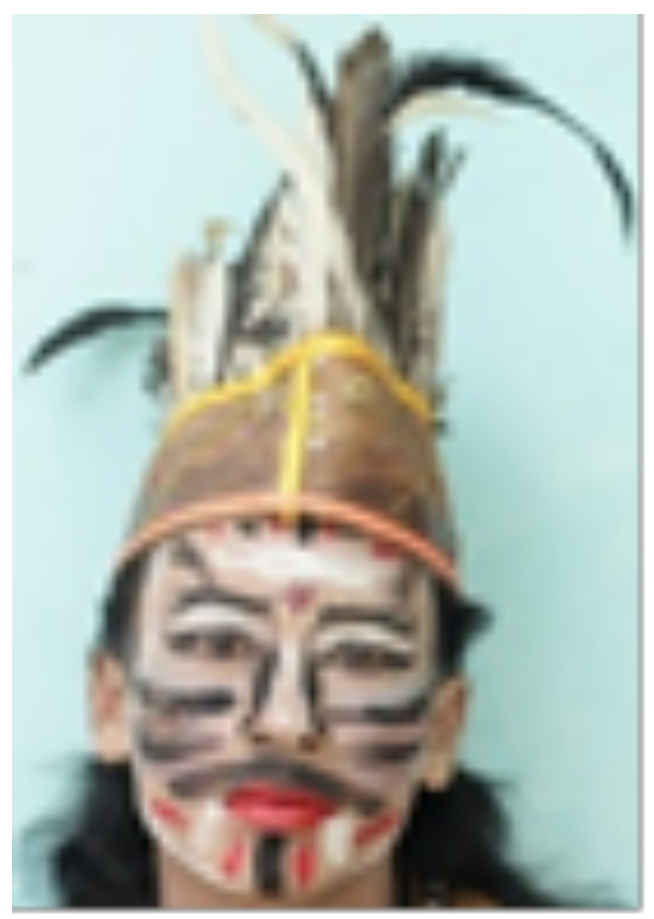

Gambar 4. Tata Rias Pemain Buncis Angklung (Dokumentasi: Rifiana Abdul Razzak, 2016) 
Begitu pula dengan busana dan aksesoris tambahan seperti mahkota yang terbuat dari bulu ayam (lihat gambar 4), kalung kace, serta celana yang dihiasi kain rumbai-rumbai, terkadang kalung dan rumbai celana menggunakan batang pohon padi yang sudah kering (damen). Lihat gambar 5(a) dan 5(b) di bawah ini.

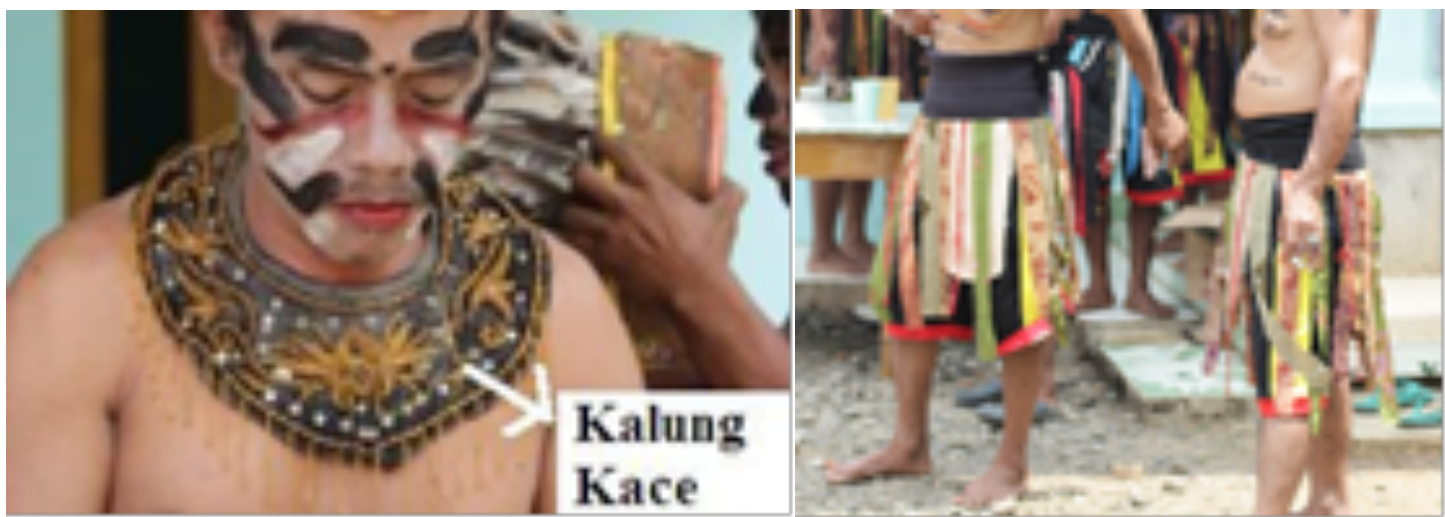

Gambar 5(a) Kalung Kace, dan gambar 5(b) Celana Rumbai-rumbai (Dokumentasi: Rifiana Abdul Razzak, 2016)

Tata Rias digunakan untuk memberikan aksentuasi bentuk-bentuk hingga pemain sebuah kesenian dapat dilihat dari kejauhan (Soedarsono, 1999, p. 108). Selain terkait dengan sejarah atau babad Desa Tanggeran, tata rias dan tata busana tersebut merupakan sebuah representasi dari kondisi masyarakat Tanggeran. Masyarakat Tanggeran merupakan masyarakat yang jauh dari gaya hidup hedonis, karena Desa Tanggeran terletak di daerah perbukitan sehingga gaya hidupnya sederhana, tanpa bermewah-mewahan. Hal tersebut tercermin dalam aksentuasi rias dan busana kesenian Buncis Angklung yang sederhana dan terkesan seperti "masyarakat suku pedalaman".

\section{Tahap Pertunjukan (Performance)}

Tahap pelaksanaan pertunjukan atau performance, yaitu tahap saat kesenian Buncis Angklung sedang berlangsung. Terdapat beberapa elemen penting diantaranya: (1) pemain Buncis Angklung, (2) bentuk musik dan lagu yang digunakan dalam pertunjukan, (3) gerakan atau tarian, (4) latar atau setting tempat, dan (5) urutan sajian atau babak penyajian. Elemenelemen tersebuat merupakan rangka pokok dari kesenian Buncis Angklung yang harus ada dalam setiap pertunjukannnya. Seperti yang telah diungkapkan (Cahyono, 2014, pp. 46-47) salah satu unsur pokok dalam sebuah pertunjukan atau performance adalah sebuah peristiwa yang terancang baik secara ketat maupun longgar (tempatnya, waktunya, pesertanya, aturannya) yang membedakan pertunjukan dengan peristiwa lain yang terjadi secara kebetulan.

Sarwono (40 tahun) selaku pelaku kesenian Buncis Angklung berpendapat bahwa saat ini kesenian tersebut dipentaskan dengan tujuan sekedar melestarikan kesenian tradisional asli dari Desa Tanggeran. Buncis Angklung pada dasarnya dilakukan oleh sembilan orang diantaranya adalah enam orang pemain angklung yang sekaligus menari di area panggung, satu orang memainkan kendang, satu orang memainkan kempul, dan seorang sinden. Paguyuban seni Buncis Angklung "Ngudi Utomo" memiliki dua kelompok yang berjumlah tiga belas orang, dua orang perias, dua orang yang mengurus uborampe sajen, dan tiga orang penimbul. Selanjutnya anggota yang lain memegang peran sebagai pemain angklung pengganti, ketika pemain angklung utama mengalami trance atau kesurupan indang. Namun demikian, aktivitas trance atau kesurupan terkadang tidak menjadikan pemain angklung 
hilang kendali dalam memainkan lagu. Meskipun pemain sedang mengalami trance, mereka masih melakukan permainan angklung seperti halnya dalam kondisi sadar. Pemain kesenian Buncis Angkung diantaranya Sarwono (40 tahun), Sanraji Samin (70 tahun), Misan (48 tahun), Sumarno (38 tahun), Satim (52 tahun), Radam (42 tahun), Warto (52 tahun), Daman (52 tahun), Awin (50 tahun), Sulastri (47 tahun), Nartem (58 tahun), Trisno (40 tahun), Rasmin (52 tahun), Saidi (38 tahun).

Lagu-lagu yang dimainkan dalam pertunjukan Buncis Angklung adalah lagu-lagu tradisional Banyumasan (gendhing Banyumasan) seperti Ricik-Ricik, Blendrong, Gudril, Pacul Gowang, Renggong Manis, Dan Eling-Eling. Semua lagu yang dibawakan bertujuan untuk menghibur dan memberikan kepuasan dengar para penonton. Dari beberapa judul gendhing yang dibawakan, terdapat satu lagu yang khusus digunakan untuk mengantar sampai ke babak trance, yaitu lagu eling-eling. Lagu eling-eling dinyanyikan oleh seorang sinden dengan iringan alat musik angklung, gong bumbung, kempul, dan kendang. Iringan musik yang dihasilkan berbeda dengan iringan musik yang dimainkan oleh gamelan atau calung. Perbedaannya terletak pada ritme-ritme yang dihasilkan. Buncis Angklung yang tergolong musik tradisional menggunakan tangga nada pentatonik slendro, yaitu tersusun dari nada ro, lu, mo, nem, ji.

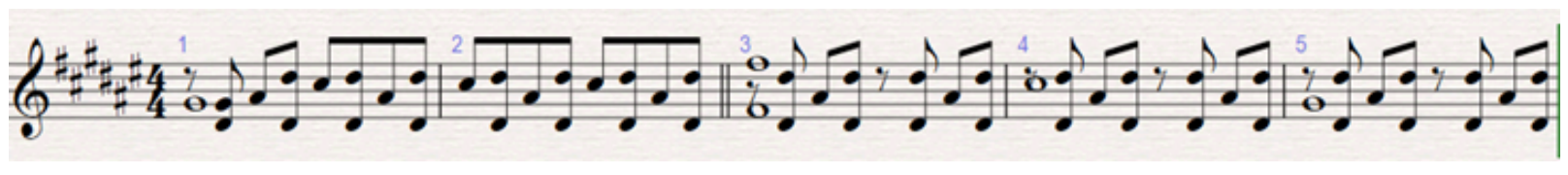

Gambar 6. Ritme Lagu Eling-Eling dalam Komposisi Angklung (Sumber: Rifiana Abdul Razzak, 2017)

Etnomusikologi sebagai studi musik tradisional, diajarkan atau diwariskan secara lisan, tidak melalui lisan, dan selalu mengalami perubahan (Supanggah, 1995). (Virganta \& Sunarto, 2016, p. 35) menjelaskan perbedaaan ciri-ciri nyanyian rakyat dengan nyanyian pop dan nyanyian seriosa adalah penyebarannya yang melalui lisan, sehingga bersifat tradisi lisan dan dapat menimbulkan varian-varian. Tercipta pola-pola ritme yang berbeda dengan iringan musik calung atau gamelan, walaupun timbre yang dihasilkan sama dengan calung. Teknik memainkan angklung secara turun temurun dilakukan oleh masyarakat Desa Tanggeran dari jaman dahulu hingga sekarang, meskipun mengalami perubahan-perubahan.

Angklung merepresentasikan tombak yang digunakan oleh Raden Patah Haji dalam pelariannya dari kejaran Patih Sundara. Dalam hal ini, angklung merupakan properti tari yang sekaligus dimainkan sebagai alat musik pengiringnya. Jika dilihat sebagai sebuah tarian menurut perkembangannya, Buncis Angklung tergolong sebagai tari tradisional kerakyatan, yaitu sebuah tarian yang tumbuh secara turun-temurun dalam lingkungan masyarakat etnis, atau berkembang dalam rakyat (Hidajat, 2005, p. 15).

Gerakan-gerakan yang digunakan sangat sederhana dan tidak rumit seperti tariantarian tradisional pada umumnya. Pemain angklung (penari) saat memasuki stage melakukan lumaksono atau berjalan yang kemudian setelah semua penari masuk, dilanjutkan dengan lumkasono muter atau berjalan memutari stage. Selanjutnya, penari melakukan gerakan ngidek ngarep yang berarti meginjakan kaki ke depan secara bergantian. Kemudian, penari melakukan gerakan junjungan atau mengangkat salah satu kaki yang dilanjutkan dengan gerakan lampah tigo. Setelah itu dilanjutkan dengan gerakan lumaksono dalam pola lantai melingkar, sehingga lingkaran berubah semakin kecil dan jarak antar penari semakin dekat. 
Kemudian kembali lagi ke posisi awal. Terdapat gerakan-gerakan yang lain seperti ogek lambung, paceg gulu, gerakan onclang dan jeblos, serta gerakan-gerakan lain yang namanya tidak teridentifikasi oleh jenis-jenis gerakan tari klasik.

Kesenian Buncis Angklung menggunakan dua pola lantai yaitu pola lantai melingkar dan tegak lurus berhadapan. Gerakan lumaksono, junjungan, paceg gulu, ogek lambung, ngidek ngarep, dan lampah tigo terjadi pada pola lantai melingkar. Hal tersebut menggambarkan pelarian seorang Raden Patah Haji yang diceritakan berlari dan bersembunyi sampai pulau Kalimantan dan menyamar seperti orang Dayak, sedangkan gerakan onclang dan jeblos terjadi pada pola lantai tegak lurus berhadapan, yang mengisahkan peperangan antara Raden Patah Haji dengan Patih Sundara. Di bawah ini merupakan gambar 7(a) untuk pola lantai melingkar dan gambar 7(b) untuk pola lantai tegak lurus berhadapan.
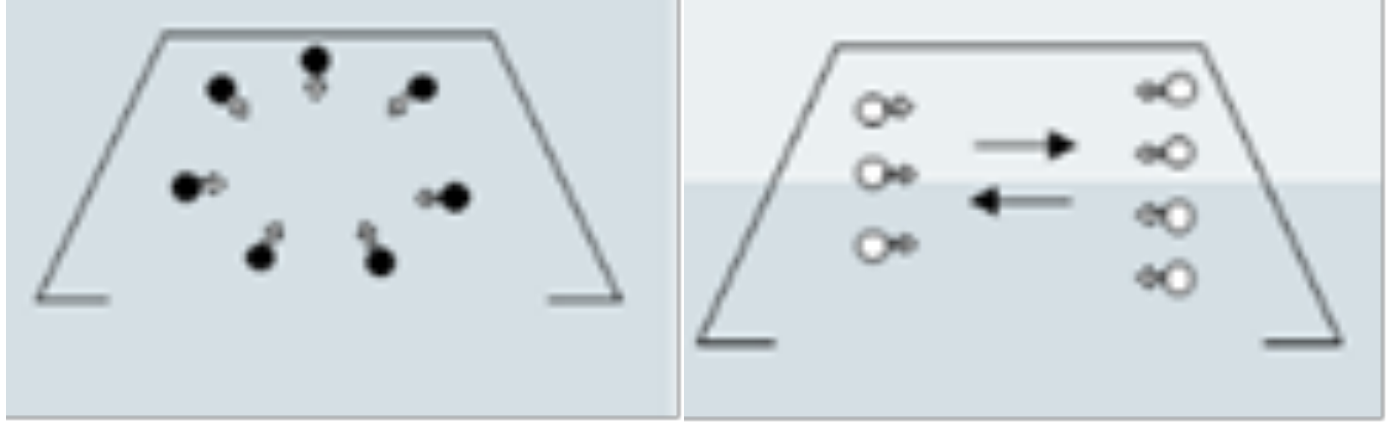

Gambar 7(a) Pola Lantai Melingkar (kiri) dan gambar 7(b) Pola Lantai Tegak Lurus Berhadapan (kanan) (Sumber: Google Search, 2017)

Buncis Angklung memiliki pola-pola lantai dan gerakan yang membutuhkan ruang gerak yang luas. Kesenian Buncis Angklung dapat dipentaskan di mana saja dengan syarat ukuran stage minimal panjang 10 meter dan lebar 8 meter yang digunakan oleh para pemain angklung untuk bergerak dan melakukan pola-pola lantai.

Buncis Angklung terdapat dua bagian utama atau babak, yaitu babak tarian keprajuritan dan babak masuknya indang atau trance. Babak tarian keprajuritan merupakan bagian awal pertunjukan Buncis Angklung. Sebelum pemain memasuki stage, terdapat pembukaan yang menampilkan lagu-lagu Banyumasan dan campursari seperti Waru Doyong dan Kembang Boled. Setelah pembukaan, para pemain angklung mulai masuk ke dalam area pertunjukan atau panggung sambil memainkan angklung yang dibawa oleh masing-masing pemain sesuai dengan lagu yang sedang dimainkan. Masuk ke area pertunjukan dengan berbaris, satu per satu pemain Buncis Angklung membentuk pola lingkaran di dalam panggung, melakukan gerakan-gerakan gagahan seperti yang terdapat pada tari keprajuritan dan secara bersamaan memainkan angklung mengikuti alur lagu-lagu Banyumasan tersebut. Setelah itu terdapat pula pola tegak lurus berhadapan. Peralihan dari pola lingkaran menjadi pola tegak lurus berhadapan diawali dengan gerakan melingkar mengitari area stage seperti pergerakan di awal saat pemain angklung memasuki area stage. Gerakan-gerakan yang terjadi adalah junjungan, tranjal, onclang, dan jeblos. Akhir dari pola lantai tersebut adalah kembali pada gerakan mengitari stage dengan pola lantai lingkaran. Bagian ini merupakan akhir dari babak pertama dan selanjutnya memasuki babak trance atau kesurupan.

Babak trance merupakan babak terakhir dalam kesenian Buncis Angklung, ditandai dengan masuknya penimbul sebagai pemanggil indang atau roh-roh halus dalam kepercayaan masyarakat Tanggeran. Penimbul adalah seseorang yang bertugas memanggil indang (roh 
halus) dan mengeluarkan indang dari raga pemain angklung yang mengalami kesurupan. Terdapat tiga penimbul dalam sebuah kelompok kesenian Buncis Angklung bernama Sanraji Samin, Sakun, dan Salimin.

\section{Tahap Setelah Pertunjukan (After Performance)}

Setelah usai penonton satu per satu meninggalkan area pertunjukan. Tempat pertunjukan yang dimaksud adalah lapangan desa atau halaman rumah Samin yang tergolong luas. Penonton tidak hanya berasal dari Desa Tanggeran saja, tetapi ada yang berasal dari luar Desa Tanggeran, seperti Desa Sokawera, Desa Somakaton, Desa Somagede, bahkan dari desa yang jauh letaknya dari Desa Tanggeran. Setelah penonton pun akhirnya pulang, para pemain Buncis Angklung ternyata masih melakukan aktivitas, seperti membersihkan rias wajah, membersihkan badan, mencopot kostum rumbai-rumbai, dan lain sebagainya. Apabila pertunjukan berakhir pada tahap trance, maka setelah pertunjukan selesai penimbul melakukan ritual-ritual tertentu guna mengusir indang-indang yang masih berada di area pertunjukan. Penimbul atau pawang mengembalikan indang ke tempat asalnya dengan menggunakan kalimat-kalimat mantra dan siraman air bunga di sekitar area pertunjukan.

Selain penimbul (pawang) dan pemain Buncis Angklung, aktivitas setelah pertunjukan juga terdapat pada pihak-pihak yang ikut mendukung kesuksesan pertunjukan, seperti pihak soundsystem. Setelah pertunjukan benar-benar selesai, crew dari pihak soundsystem segera mematikan microphone dari mixer, mencopotinya, lalu menggulung kabel-kabel yang digunakan dan membungkus satu persatu alat-alat lain, seperti stand mic, passive speaker, mixer, VCD player, dan lain sebagainya. Gotong-royong dan rasa kekeluargaan tercermin dari perilaku warga Grumbul Lampeng yang ikut membersihkan area pertunjukan dari sampahsampah makanan, bunga-bunga bekas sesaji, maupun sampah lain yang berserakan di stage. Warga Grumbul Lampeng merasa memiliki kesenian Buncis Angklung hingga pada akhir pementasannya pun tanpa ada perintah apapun, warga ikut membawa alat-alat kebersihan guna membersihkan area stage (halaman rumah Samin maupun balai desa).

\section{Pembahasan}

\section{Makna Semiotik Kesenian Buncis Angklung bagi Masyarakat Tanggeran}

Ciri dari kajian pertunjukan yaitu pertunjukan yang mewujud dalam ruang, waktu, konteks sosial dan budaya masyarakat pendukungnya (Pudentia, 2015, p. 11). Hasil utamanya berupa wigati atau makna yang berguna bagi penonton pertunjukan dan atau masyarakat (Cahyono, 2014, p. 27). Konsep semiotika pertunjukan Marco de Marinis dan Tadeuzs Kowzan digunakan untuk membantu mengungkap makna yang terdapat dalam sebuah kajian pertunjukan. Tadeuz Kowzan (Aston \& Savona, dalam Cahyono 2014:49) mengatakan bahwa dalam pertunjukan terdapat tiga belas sistem tanda, yaitu: (1) tanda kata, (2) nada, (3) mimik, (4) gerakan-gerakan, (5) gerak isyarat, (6) tata rias, (7) gaya rambut, (8) kostum, (9) properti, (10) setting, (11) tata cahaya, (12) musik, dan (13) pengaruh bunyi. Seni pertunjukan secara tekstual dipahami sebagai wujud atau struktur bentuk fisik (teks), secara empirik dapat dilihat dan didengar (Hadi 2012, dalam Septiana). Aspek yang terdapat dalam sebuah pertunjukan antara lain musik dan lagu, pemain atau pelaku seni pertunjukan, gerakan pemain (koreografi/tarian), perlengkapan pementasan (kostum), tempat, dan urutan sajian. Sistem tanda dari Kowzan digunakan untuk mengkaji tentang kesenian Buncis Angklung, namun 
hanya dipilih beberapa sistem tanda yang dianggap relevan dengan aspek-aspek dalam sebuah pertunjukan seperti: (1) tanda nada atau musik, (2) pengaruh bunyi, (3) setting, (4) kostum, (5) properti, (6) tata rias, dan (7) gerakan-gerakan.

Musik merupakan hasil karya seni dalam bentuk lagu atau komposisi-komposisi musik yang mengungkapkan pikiran dan perasaan penciptanya melalui unsur-unsur musik yaitu irama, melodi, harmoni, bentuk atau struktur dan ekspresi sebagai salah satu kesatuan. Kesenian Buncis Angklung memiliki irama musik angklung yang rancak atau ramai (penanda), berarti bahwa masyarakat Banyumas egaliter dan mudah bersosialisasi atau grapyak (petanda).

Musik merupakan jenis kesenian yang dicerap oleh indera pendengaran. Buncis Angklung melibatkan seni musik sekaligus seni tari dalam sebuah pementasan (Sinaga, 2020). Musik diterima oleh para pemain Buncis Angklung sebagai iringan dalam melakukan gerakangerakan gagahan, atau dengan kata lain musik (bunyi) memiliki pengaruh terhadap tarian yang dilakukan para pemain. Pada saat pertunjukan akan segera dimulai, kendang ditabuh pertama kali (penanda), maka pemain akan memainkan lagu pertama menggunakan angklung mengikuti alur lagu dan tempo yang diciptakan oleh pemain kendang. Hal tersebut memiliki makna (petanda) bahwa setiap manusia yang hidup di dunia harus mematuhi aturan-aturan kehidupan (Al-Quran dan Hadits) agar tidak tersesat ke jalan yang salah, sebagai contoh untuk memulai segala sesuatu hendaknya dimulai dengan bacaan bismillahirrahmanirrahim.

Pengaruh bunyi yang lain terdapat dalam judul lagu. Ketika pertunjukan Buncis Angklung memainkan lagu tradisional Banyumasan yang berjudul eling-eling (penanda), maka pemain Buncis Angklung akan mengalami wuru' atau kesurupan. Lagu berjudul eling-eling memiliki makna (petanda) bahwasanya kita sebagai manusia yang hidup di dunia harus selalu mengingat mati atau kehidupan setelah mati yang harus dipersiapkan dengan baik. Sebagai contoh pada lirik lagu eling-eling yang berbunyi "eling-eling wong eling baliya maning" yang berarti orang yang hidup di dunia ini harus ingat (eling berarti ingat) kepada kematian (baliya maning bermaksud kembali pada Tuhan Yang Maha Kuasa).

Setting atau tempat pertunjukan Buncis Angklung tidak memiliki ketentuan-ketentuan khusus jika tidak berfungsi sebagai ritual Baritan. Buncis Angklung yang berfungsi sebagai media komunikasi dalam ritual Baritan, tempat pelaksanaannya akan diatur sedemikian rupa sesuai dengan perhitungan-perhitungan Jawa (weton) dan latar tempat yang memiliki aura supranatural kuat atau dianggap keramat oleh masyarakat (Soedarsono, 1998:60). Tempat pertunjukan kesenian Buncis Angklung untuk ritual Baritan salah satunya adalah balai desa Tanggeran. Balai desa merupakan sebuah pusat pemerintahan di tingkat Desa (penanda). Dalam konteks kehidupan, masyarakat meyakini bahwa manusia akan kembali ke sebuah titik/pusat setelah kematian di dunia (petanda). Selain balai desa, lapangan desa juga digunakan sebagai tempat pementasan Buncis Angklung dalam ritual Baritan. Lapangan merupakan tempat yang luas dan cocok digunakan untuk mementaskan Buncis Angklung (penanda). Masyarakat meyakini bahwa Tuhan akan membukakan pintu rejeki seluas-luasnya bagi setiap hamba-Nya yang taat beribadah (petanda).

Busana yang digunakan dalam pertunjukan kesenian Buncis Angklung merupakan busana atau kostum sederhana (penanda), yaitu terdiri dari kain rumbai-rumbai yang digunakan sebagai penghias celana pendek, kalung kace, dan hiasan di kepala berbentuk menyerupai makhkota yang terbuat dari susunan bulu ayam. Bahkan terkadang kalung kace dan kain rumbai-rumbai diganti dengan batang pohon padi yang telah menguning (Banyumas: 
damen). Hal tersebut memiliki makna (petanda) bahwa manusia hidup di dunia harus dengan kesederhanaan meskipun diberikan kelimpahan harta. Berbusana sederhana merupakan cerminan dari sikap rendah hati.

Properti atau kelengkapan yang dimaksud adalah angklung dan sesaji atau uborampe sajen. Angklung merupakan alat musik (penanda) yang terbuat dari bambu dan dimainkan dengan cara digoyangkan sehingga bambu angklung yang tersusun saling bersentuhan dan mengeluarkan bunyi (nada) tertentu, memiliki makna (petanda) yaitu sebuah perkataan atau ucapan manusia. Angklung dimainkan secara selaras sehingga mengeluarkan bunyi yang harmonis. Hal ini memiliki maksud bahwa setiap ucapan seseorang hendaknya berkata yang baik dan bermanfaat bagi orang lain. Sajen atau sesaji merupakan ciri khas dan salah satu syarat utama dalam ritual Baritan yang harus dipenuhi (Soedarsono, 1998:60). Salah satu uborampe sajen dalam ritual Baritan adalah kelapa hijau (penanda). Kelapa hijau yang dikupas oleh pemain Buncis Angklung memiliki makna yaitu sebagai petanda bahwa akan turun hujan (petanda).

Pemain angklung menggunakan rias wajah dan badan dengan kombinasi warna merah, hitam dan putih (penanda). Makna dari rias wajah yang digunakan dalam kesenian Buncis Angklung adalah nilai kesederhanaan (petanda). Manusia hidup di dunia hendaknya hidup dalam kesederhanaan, menjauhi sifat berfoya-foya, dan sebagainya. Secara keseluruhan, tata rias dan busana yang digunakan oleh para pemain angklung dalam kesenian Buncis Angklung merupakan potret atau gambaran kondisi masyarakat Tanggeran serta dikaitkan dengan sejarah atau babad Desa Tanggeran.

Gerakan-gerakan atau tarian yang terdapat dalam Buncis Angklung diawali dengan pola lantai lingkaran dengan gerakan lumaksana (penanda) atau berjalan memutar sambil memainkan angklung sesuai dengan alur lagu. Gerakan tersebut merupakan sebuah penanda yang memiliki makna (petanda) bahwa dalam berkehidupan bermasyarakat harus selalu menjunjung tinggi kerukunan (pola lantai lingkaran), kekompakan, dan persatuan. Selanjutnya, terdapat gerakan onclang jeblos, yaitu gerakan dengan pola lantai berhadapan kemudian berjalan (onclang) berpapasan (jeblos) merupakan sebuah penanda. Gerakan onclang memiliki makna (petanda) kebahagiaan atau kegembiraan, sedangkan gerakan jeblos memiliki makna (petanda) segala permasalahan yang ada di dalam kehidupan hendaknya diselesaikan secara tuntas tanpa meninggalkan permasalahan lain.

\section{Kesimpulan}

Buncis Angklung yang beasal dari Desa Tanggeran merupakan pertunjukan tari dengan penari memainkan alat musik angklung sebagai musik iringannya. Dalam pertunjukannya Kesenian Buncis Angklung dibagi menjadi tiga bagian pertunjukan, yaitu sebelum pertunjukan dimulai dari pemain angklung melakukan rias terlebih dahulu. Rias wajah atau make up, rias tubuh atau body painting, serta busana. Pada tahap pertunjukan, Buncis Angklung terdapat dua bagian utama atau babak, yaitu babak tarian keprajuritan dan babak masuknya indang atau trance. Paska pertunjukan ditandai dengan melepas kostum dan membersihkan make up para pemain, namun ketika pertunjukan berakhir pada tahap trance, maka setelah pertunjukan selesai penimbul melakukan ritual-ritual tertentu guna mengusir indang-indang yang masih berada di area pertunjukan. Dalam teks pertunjukan Buncis Angklung dapat ditemukan adanya makna religius dan makna relasi. Makna religius yaitu adanya hubungan 
manusia dengan penciptanya (Tuhan), sedangkan makna relasi yang dimaksud adalah relasi manusia dengan sesama manusia sebagai makhluk ciptaan Tuhan.

\section{Referensi}

Cahyono, A. (2014). Makna Teks Pertunjukan Barongsai Dalam Upacara Ritual Imlek. Tonil Jurnal Kajian Sastra, Teater, Dan Sinema, 11(1), 45-64.

Creswell, J. W. (2016). Research Design: Pendekatan Metode Kualitatif, Kuantitatif, Dan Campuran. Yogyakarta: Pustaka Pelajar, 5.

Giri, W. (2010). Sajen Dan Ritual Orang Jawa. Penerbit Narasi.

Hidajat, R. (2005). Wawasan Seni Tari: Pengetahuan Praktis Bagi Guru Seni Tari. Jurusan Seni Dan Desain, Fakultas Sastra, Universitas Negeri Malang.

Indrayati, E. N. (2015). Kesenian Buncis Daerah Banyumas. Seminar Nasional Evaluasi Pendidikan li.

Kuwat, S. H. (1999). Kesinambungan Benang Merah Bongkel, Buncis, Krumpyung, Dan Calung Banyumas Continuity And Connections In Bongkel, Buncis, Krumpyung, And Calung From Banyumas. Sosiohumanika, 12(1999).

Merdiana, E. (2013). Makna Dalam Media Tradisional Angklung Buncis Sebagai Kearifan Lokal Kota Cimahi (Studi Etnografi Komunikasi Dengan Pendekatan Interaksi Simbolik Mengenai Makna Dalam Media Tradisional Angklung" Budaya Urang Nurutkeun Ciri Sunda" Kampung Adat Cireundeu Se. Universitas Komputer Indonesia.

Permanasari, Alis Triena; Setian, D. D. R. S. (2020). Kesenian Gendreh: Bentuk Dan Respon Estetis Pola Tabuh Alu - Lisung Di Kampung Bojong Rangkasbitung. Musikolastika, 2(2).

Pudentia, M. (2015). Metodologi Kajian Tradisi Lisan (Edisi Revisi). Yayasan Pustaka Obor Indonesia.

Putra, A. D. (2017). Estetika Sema Dalam Tarekat Sufi Naqsybandi Haqqani Jakarta Sebagai Media Penanaman Pendidikan Tauhid. Gondang: Jurnal Seni Dan Budaya, 1(1), 26-39. Http://Jurnal.Unimed.Ac.Id/2012/Index.Php/Gdg

Rohendi Rohidi, T. (2011). Metode Penelitian Seni. Semarang: Cipta Prima Nusantara Semarang.

Sabar, S. S., \& Wiyoso, J. (2018). Nilai Moral Pada Kesenian Buncis Di Desa Tanggeran Kecamatan Somagede Kabupaten Banyumas. Jurnal Seni Tari, 7(2), 1-9.

Saputra, M. A. (2015). Perkembangan Kesenian Angklung Buncis Di Kecamatan Cigugur Kabupaten Kuningan Tahun 1980-2010. Universitas Pendidikan Indonesia.

Schechner, R. (2013). What Is Performance Studies. Rupkatha Journal On Interdisciplinary Studies In Humanities, 5(2), 2-11.

Schechner, R., \& Lucie, S. (2020). Performance Studies: An Introduction. Routledge.

Septiana, O., Sumaryanto, T., \& Cahyono, A. (2016). Nilai Budaya Pertunjukan Musik Terbangan Pada Masyarakat Semende. Catharsis, 5(2), 142-149.

Sinaga, F. S. S. (2020). Musik Trunthung Sebagai Wujud Kearifan Lokal Dalam Konteks Pendidikan Seni. Tonika: Jurnal Penelitian Dan Pengkajian Seni, 3(1), 27-38. 
Sinaga, F. S. S. (2016). Musik Trunthung Sebagai Media Ekspresi Masyarakat Warangan. Seminar Antar Bangsa, 161-174. Https://Doi.Org/10.31227/Osf.lo/Wc4vy

Soedarsono, R. . (1999). Seni Pertunjukan Indonesia Dan Parisiwata. Mspi.

Sugono, D. (2013). Mahir Berbahasa Indonesia Dengan Benar. Gramedia Pustaka Utama.

Supanggah, R. (1995). Etnomusikologi. Yayasan Betang Budaya.

Sutopo, B., Hendriyanto, A., Mustofa, A., \& Pacitan, S. P. (2019). Respons Estetis Generasi Muda Terhadap Pertunjukan Seni Kethek Ogleng: Studi Pada Kegiatan Road Show Kethek Ogleng Di Objek Wisata Kabupaten Pacitan. 143-149.

Virganta, A. L., \& Sunarto, S. (2016). Bentuk Nyanyian Rakyat Dalam Seni Sastra Senjang Di Kabupaten Musi Banyuasin. Catharsis, 5(1), 34-40.

Winangsit, E., \& Sinaga, F. S. S. (2020). Esensi Pendidikan Musik Berbasis Industri Budaya Di Tengah Pandemi Covid-19. Prosiding Seminar Nasional Pascasarjana (Prosnampas), 3(1), 989-995. 